\title{
Drive Cycle Simulations of Wheeled and Tracked Heavy- Duty Electric Vehicle Powertrains
}

\section{Tekerlekli ve Paletli Elektrikli Ağır Hizmet Aracı Tahrik Sisteminin Sürüş Çevrimi Simülasyonları}

\author{
Eda Alpaslan 1(D), Mustafa Umut Karaoğlan ${ }^{*}{ }^{\mathbb{D}}$, C. Ozgur Colpan ${ }^{3}(\mathbb{D}$ \\ ${ }^{1}$ Dokuz Eylul University, The Graduate School of Natural and Applied Sciences, Mechanical Engineering Department, \\ Buca, Izmir, 35390, TURKEY \\ 2 Dokuz Eylul University, Engineering Faculty, Department of Mechanical Engineering, Buca, Izmir, 35390, TURKEY \\ ${ }^{3}$ Dokuz Eylul University, Engineering Faculty, Department of Mechanical Engineering, Buca, Izmir, 35390, TURKEY \\ Sorumlu Yazar / Corresponding Author*: mustafa.karaoglan@deu.edu.tr
}

\author{
Gelis Tarihi / Received: 12.01.2021 Arastırma Makalesi/Research Article \\ Kabul Tarihi / Accepted: 30.03.2021 DOI:10.21205/deufmd.2021236919 \\ Atıf șekli/How to cite: ALPASLAN E.,KARAOGLAN M.U., COLPAN C.O.(2021). Drive Cycle Simulations of Wheeled and Tracked Heavy-Duty \\ Electric Vehicle Powertrains. DEUFMD 23(69), 913-921.
}

\begin{abstract}
Heavy-duty electric vehicle applications are becoming more popular in transportation, construction, and military applications because of the emission targets of several countries. Therefore, to obtain an efficient and clean heavy-duty electric vehicle, simulation of the powertrain is performed according to various vehicle weights and drive types for the determination of vehicle performance. In this study, the drive cycle simulation of a heavy-duty electric vehicle is performed by Matlab/Simulink for both wheeled and tracked drive alternatives. Battery power requirements and SOC (State of Charge) history are determined according to the drive cycle of HHDDT (Heavy Heavy-Duty Diesel Truck) Transient Mode and Cruise Mode for constant vehicle weight and battery capacity. On the other hand, the climbing potential of vehicles is calculated during the drive cycle. According to the results, the range of wheeled vehicle is found higher than that of the tracked versions, however, the climbing potential of the tracked vehicle is found more advantageous than that of the wheeled type.

Keywords: Electric vehicle simulation, heavy duty vehicle, tracked vehicle, wheeled vehicle

Öz

Ağır hizmet tipi elektrikli araç uygulamaları, birçok ülkenin emisyon hedefleri nedeniyle ulaşım, inșaat ve askeri uygulamalarda daha popüler hale geliyor. Bu nedenle, verimli ve temiz bir ağır hizmet elektrikli araç elde etmek için, araç performansının belirlenmesi için çeşitli araç ağırlıklarına ve tahrik tiplerine göre güç aktarma bileşenlerinin simülasyonu yapılır. Bu çalışmada, ağır hizmet tipi bir elektrikli aracın sürüş çevrimi simülasyonu, hem tekerlekli hem de paletli tahrik alternatifleri için Matlab/Simulink ortamında gerçekleştirilmiştir. Batarya gücü gereksinimleri ve SOC (Şarj Durumu) geçmişi, sabit araç ağırlığı ve batarya kapasitesi için HHDDT (Ağır Ağır Hizmet Dizel Kamyon) Geçici Modu ve Seyir Modunun sürüş döngüsüne göre belirlenir. Öte yandan, sürüş çevrimi sırasında araçların yokuş çıkma kabiliyeti hesaplanır. Sonuçlara göre tekerlekli tipteki aracın menzili paletli tiptekine göre daha yüksek bulunurken, paletli aracın yokuş çıkma kabliyeti tekerlekli tipe göre daha avantajlı bulunmuştur.
\end{abstract}

Anahtar Kelimeler: Elektrikli araç simülasyonu, ağır hizmet aracı, paletli araç, tekerlekli araç 


\section{Introduction}

Heavy duty vehicles are commonly used in transport, military defense, and special purpose truck applications. As a result of the developments in electric vehicle technology in recent years, conventional heavy vehicles have been started to transform into heavy electric vehicles as they are more efficient and safer. The electrical and hybrid alternatives of the heavy vehicles are also used in the military field. However, fieldwork of the hybrid electric military vehicles has been much slower than commercial vehicles due to the technical difficulties that must be overcome in order to be considered suitable for military applications in hybrid vehicle technology [1].

Many studies have focused on the development of electric and hybrid heavy vehicles with wheeled and tracked types in the literature. For military applications, hybrid powertrain technology offers significant benefits on the vehicle performance in terms of grading performance and exhaust emissions [1]. His study showed that new battery technologies become increasingly suitable for military applications and a typical Diesel-Electric mining truck, which was modeled in the Matlab/Simulink environment to perform fuel efficiency assessment and cost benefit analysis under real world conditions [2]. The overall performance of the electric heavy-duty truck vehicle was modeled by Verbruggen et al. (2019) using Matlab simulation package to analyze the energetic benefits of a multispeed transmission compared to a single speed transmission for a long-haul truck [3]. The results showed the potential of decreasing the size of an electric motor and increasing the climbing potential of the vehicle with the usage of a multi-speed transmissions for trucks. Hohl et al. (2007) discussed the historical background, current developments, and future aspects of the most important wheeled and tracked military hybrid vehicle systems [4]. Recent advancements in sustainable transportation have led to the release of commercially available fuel cell electric vehicles (FCEVs). The modeling and analysis of commercial medium and heavy-duty

vehicles operated by hydrogen fuel cells were presented by Kast et al. (2017) to examine vehicle performance under various driving cycles [5].
Many studies have been conducted on vehicle modeling for heavy duty vehicles including vehicle dynamics and powertrain component modeling in the literature. For example, a powertrain system model was developed to determine the energy requirements of vehicles using mathematical models of both conventional and mild hybrid powertrain mechanisms [6]. For the simulations of electric heavy vehicles, the powertrain model was used with longitudinal vehicle dynamics approach including rolling, aerodynamics, and acceleration resistance forces [7]. Analysis of hybrid electric tracked vehicle was presented using dynamic and kinematic vehicle motion model, dynamic track models, and dynamic models of the transmission system in Matlab/Simulink environment to determine energy consumption of the battery [8]. Mallon et al. (2017) created a vehicle model, motor and power electronics model, battery model, and solar radiation and photovoltaics model to assess the performance of on-board photovoltaics on an electric bus [9]. Additionally, studies on the mobility of tracked vehicles have been performed by Bekker et al. (1956) and Wong (2001) [10-11]. On the other hand, Wong (2008) investigated the mechanics of vehicle-terrain interaction known as "terramechanics" using experimental data of the mechanical properties for various terrain types of off-road vehicles [12]. Kitano and Kuma (1977) developed a model to analyze steadystate and transient steering response at different speeds based on the pull-slip equation of tracked vehicles [13].

Recent studies about the modeling and simulation on the powertrain systems of hybrid heavy vehicles can be shown in the literature. A modeling and simulation study was carried out in Matlab/Simulink environment in order to evaluate the fuel saving benefits of using thermoelectric generators in hybrid heavy-duty electric vehicles according to a proper driving cycle [14]. On the other hand, another vehicle modeling and simulation study was carried out in Matlab/Simulink environment for a conventional heavy-duty vehicle with a diesel engine to design a hybrid power transmission mechanism [15]. Matlab was used as a simulation tool to simulate he powertrain of an electric heavy-duty vehicle with a new topology dimensioning approach based on the optimization [16]. 
Although there are many studies on the modeling of wheeled and tracked vehicles in the literature, performances of electric heavy vehicles have not been compared with wheeled and tracked drive types. In this study, the power requirements and SOC of the battery for a heavyduty electric vehicle with two different drive types as wheeled and tracked are modeled in Matlab/Simulink to determine vehicle performance. The results of vehicle range and climbing potential are compared for wheeled and tracked types of drive.

\section{Simulation Methodology and Vehicle Powertain Models}

Wheeled and tracked heavy-duty vehicles play an important role in the industry and military field. For this reason, wheeled and tracked versions of a heavy-duty electric vehicle are modeled to assess the vehicle performance with drive cycle simulations, which are widely preferred for simulation applications in automotive applications. In order to determine the vehicle performance such as vehicle range and climbing performance according to the operation conditions of the vehicle, a vehicle model is developed in Matlab/Simulink. The power requirement of the battery and state of charge (SOC) are calculated during the drive cycle depending on the electric motor (EM) current output. Additionally, the climbing potentials of the wheeled and tracked heavyduty electric vehicles during the cycle time are found from the simulation model. The operation condition of the vehicle is determined by the speed profile as input parameters during the driving time. In this study, calculations were made for both the HHDDT Transient and Cruise mode speed profiles for different types of vehicles. The speed profile values were defined in the simulation model as an input parameter of the simulation to calculate the EM torque output, SOC, battery power output, vehicle range, and climbing potential for two different types of vehicle drive as wheeled and tracked. To calculate these parameters, vehicle dynamic and component models are developed in Matlab/Simulink as simulation model (Figure 1a.) during the speed profile of the simulation. Additionally, vehicle dynamics blocks are shown in detail for wheeled (Figure 1b.) and tracked (Figure 1c.) vehicles.
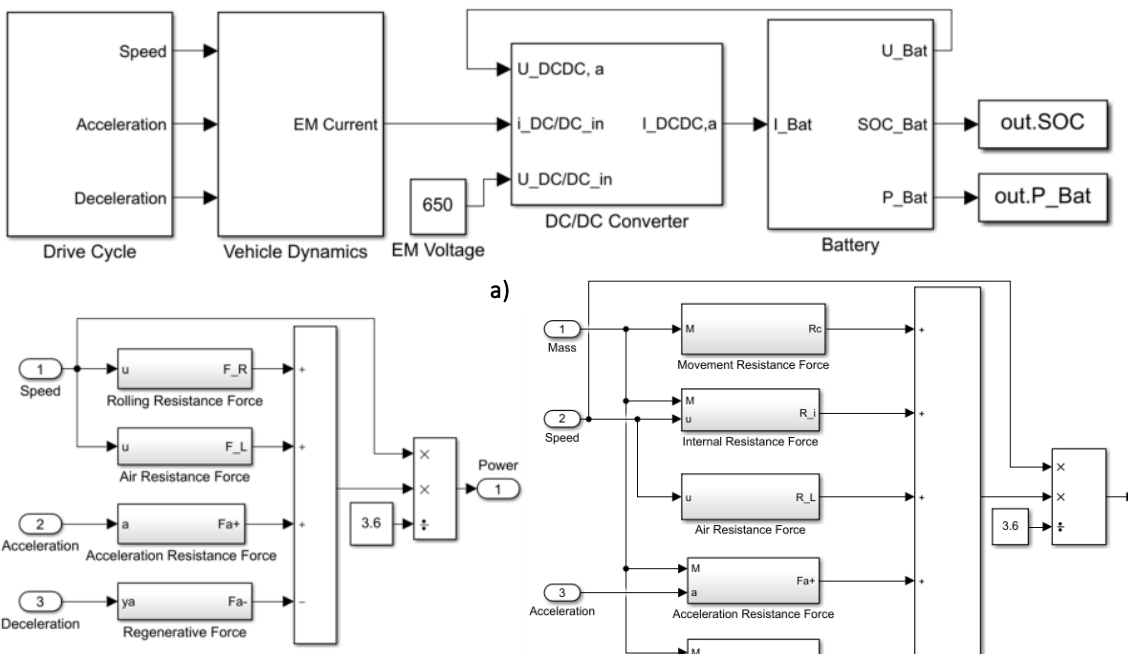

)

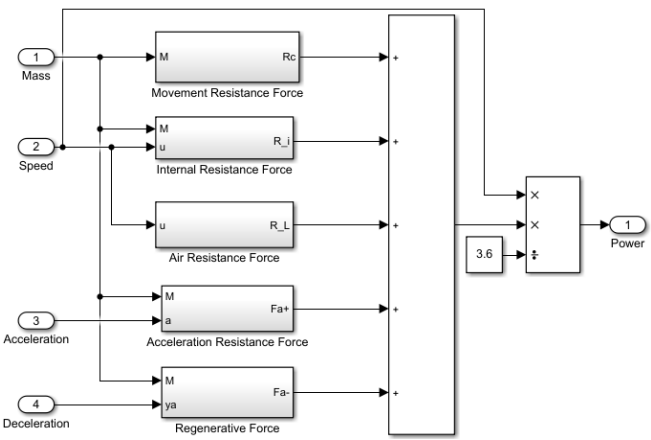

Figure 1. a) Matlab/Simulink model for electric wheeled and tracked vehicles with vehicle model details of b) wheeled and c) tracked powertrains 
The power requirement of the battery that provides current demand for the traction of an electric vehicle is modeled both for wheeled and tracked driven types of vehicles. Powertrain model are based on main assumptions such as vehicle moves only longitudinal direction, slip of the tire and the tracked mechanism are ignored, radius of the tire and the tracked mechanism are assumed as constant and the system vibration, and the damper are neglected for both wheeled and tracked heavy vehicles [17].

In order to calculate the power requirement on the battery, the vehicle must overcome total motion resistance forces during driving. The motion resistances are rolling resistance $\left(F_{R}\right)$, aerodynamic resistance $\left(F_{L}\right)$, positive acceleration resistance $\left(F_{a}\right)$ for wheeled vehicle and shown in Eqs. 1-3. Regenerative braking effect $\left(F_{a^{-}}\right)$caused by negative acceleration effect due to braking is included in the calculation as shown in Eq. 4.

$F_{R}=m \cdot g \cdot f_{R}$

$F_{L}=\frac{1}{2} \cdot c_{W} \cdot A \cdot \rho_{L} \cdot V^{2}$

$F_{a}=m \cdot a$

$F_{a}^{-}=m \cdot a^{-}$

where $V$ is the speed of the vehicle $[\mathrm{m} / \mathrm{s}], a$ is the positive acceleration $\left[\mathrm{m} / \mathrm{s}^{2}\right]$ and $a^{-}$is the negative acceleration $\left[\mathrm{m} / \mathrm{s}^{2}\right]$ for the speed profile of the vehicle according to the drive cycle, $f_{R}$ is the rolling resistance coefficient, $c_{W}$ is the aerodynamic resistance coefficient.

General specifications of drive cycle profiles are given in Table 1 for HHDDT-Transient Mode and HHDDT-Cruise Mode

Table 1. Drive cycle parameters of HHDDTTransient Mode and HHDDT-Cruise Mode

\begin{tabular}{lll}
\hline Parameter & $\begin{array}{l}\text { HHDDT } \\
\text { Transient }\end{array}$ & $\begin{array}{l}\text { HHDDT } \\
\text { Cruise }\end{array}$ \\
\hline Duration [s] & 668 & 2083 \\
Distance [km] & 2.85 & 23.07 \\
Average Speed [km/h] & 15.364 & 39.875 \\
Max. Speed [km/h] & 47.5 & 59.3 \\
Max. Acceleration [m/s $\left.\mathrm{s}^{2}\right]$ & 0.805 & 0.594 \\
Max. Deceleration $\left[\mathrm{m} / \mathrm{s}^{2}\right]$ & -0.7694 & -0.65 \\
Percent Idle [\%] & 16.3 & 8 \\
\hline
\end{tabular}


resistance resulting from the vehicle-terrain interaction. In this case, the effect that increases the motion resistance occurs as a result of the sinking in the field. In order to calculate this resistance force, $Z_{0}$, the amount of sinking into the land must first be calculated according to the Eqs. 7 and 8.

$Z_{0}=\left(\frac{P}{\frac{k_{c}}{b}+k_{\phi}}\right)^{\frac{1}{n}}$

$p=\left(\frac{m \cdot g}{b \cdot l_{t}}\right)$

where $p$ is the pressure transmitted by the pallets to the terrain, $b$ is the track width and $\mathrm{l}_{\mathrm{t}}$ is the track length. $n$ is the variable depending on the type of terrain. In addition, $k_{c}$ and $k_{\phi}$ are the variables depending on the type of terrain [11]. The resistance resulting from the vehicle-terrain interaction $\left(R_{c}\right)$ is calculated as follows depending on the sinking value and shown in Eq. 9.

$R_{c}=2 b\left(\frac{k_{c}}{b}+k_{\phi}\right) \frac{Z_{0}^{n+1}}{n+1}$

As a result of the effects of vehicle resistance forces, the power requirement value in the battery of tracked vehicle is calculated and shown in Eq. 10.

$P_{B}^{t}=\frac{\left(R_{i n}+R_{C}+F_{L}+F_{a}+F_{a}^{-} \cdot \eta_{E M} \cdot \eta_{M} \cdot \eta_{B}\right)}{\eta_{E M} \cdot \eta_{M} \cdot \eta_{B}} \cdot V$

After the calculation of the battery power requirements, the battery model aims to estimate the state of charge during the simulation time in electric vehicles. The battery can be expressed as an energy source with the Rint model. According to this model, the battery is considered as a voltage source with an internal resistance which is a function of operation conditions (charging-discharging) and opencircuit voltage of battery depending on SOC. During the simulation time, SOC is expressed in Eq. 11 according to the battery power output $\left(P_{B}\right)$ for the wheeled and tracked vehicles [19]. $S O C(t)$ is the state of charge of the battery for each simulation time and $S O C_{i}$ is the initial SOC value.

$\operatorname{SOC}(t)=\operatorname{SOC}_{i}-\frac{1}{Q_{B}} \int_{0}^{t} P_{B} \cdot d t$

where $Q_{B}$ is the total capacity [kWh] of the battery. $E_{B}$ can be defined as the total energy requirement of the batteries which is calculated by integrating the time-dependent battery power requirement throughout the cycle period and shown in Eq. 12.

$E_{B}=\int_{0}^{t} P_{B} \cdot d t$

The vehicle range $(X)$ can be calculated by Eq. 13 depending on total battery capacity and energy consumption in the battery for one cycle time.

$X=x_{\text {tot }} \cdot \frac{Q_{B}}{E_{B}}$

where $x_{t o t}[\mathrm{~m}]$ is the amount of distance the vehicle travels through the cycle.

After calculating the energy requirement in the batteries, the torque generated in the electric motor is calculated in the model. The torque requirement of the electric motor $\left(T_{E M}\right)[\mathrm{Nm}]$ is calculated with the power requirement in the electric motor $\left(P_{E M}\right)[\mathrm{kW}]$ and the rotational speed of the motor $\left(n_{E M}\right)$ [rpm]. Eqs. 14-16 the calculations of $P_{E M}, T_{E M}$, and $n_{E M}$.

$P_{E M}=\frac{P_{T}}{\eta_{E M} \cdot \eta_{M}}$

where $P_{T}$ is the total resistance power for the wheeled or the tracked vehicle.

$T_{E M}=\frac{P_{E M} \cdot 9549}{\eta_{E M}}$

$n_{E M}=\frac{V}{3.6} \cdot \frac{60}{2 \pi} \cdot \frac{i_{g}}{r_{d y n}}$

where $i_{g}$ is the overall gear ratio between traction tires or tracks and electric motor, $r_{d y n}$ is the dynamic tire radius (track radius in the tracked vehicle).

All input parameters and coefficients using the formulations are defined in Table 2. Dimensional parameters of the vehicle types are determined according to the spesifications of the proper vehicles. On the other hand, initial SOC value is defined as $80 \%$ for better understanding of the variations of the SOC during the drive cycle simulation. 
DEÜ FMD 23(69), 913-922, 2021

Table 2. Vehicle parameters for wheeled and tracked vehicle simulations

\begin{tabular}{ccc}
\hline Parameters & Value & Unit \\
\hline$m$ & 8000 & $\mathrm{~kg}$ \\
$g$ & 9,81 & $\mathrm{~m} / \mathrm{s}^{2}$ \\
$f_{R}$ & 0,03 & - \\
$\rho_{L}$ & 1,2 & $\mathrm{~kg} / \mathrm{m}^{3}$ \\
$c_{W}$ & 1 & - \\
$A$ & 7 & $\mathrm{~m}^{2}$ \\
$i_{g}$ & 12 & - \\
$r_{d y n}$ & 0.45 & $\mathrm{~m}$ \\
$l$ & 3.65 & $\mathrm{~m}$ \\
$b$ & 0.635 & $\mathrm{~m}$ \\
$n$ & 1.1 & - \\
$k_{C}$ & 0.99 & $\mathrm{kN} / \mathrm{m}^{n+1}$ \\
$k_{\varphi}$ & 1528.43 & $\mathrm{kN} / \mathrm{m}^{n+2}$ \\
$\eta_{E M}$ & 0,9 & - \\
$\eta_{M}$ & 0,9 & - \\
$\eta_{B}$ & 0,92 & - \\
$S O C_{i}$ & 0,8 & - \\
$Q_{B}$ & 250 & $\mathrm{kWh}$ \\
$\mu_{w}$ & 0,7 & - \\
$\mu_{t}$ & 0,9 & - \\
\hline
\end{tabular}

The input parameters and selected speed profile values were defined in the model created based on the formulations given above and the desired output results were calculated.

After the development of the powertrain simulation model, an important parameter in determining the performance characteristics of the vehicles, the hill climbing capability was modeled in Matlab/Simulink environment. The road hold coefficient was used to calculate the slope value, which is a measure of the ability to climb uphill. The road hold coefficient plays a decisive role in determining the performance limits of a vehicle. The total resistance forces affecting the vehicle cannot exceed the limit determined by this adhesion coefficient. The maximum slope angles $\left(\alpha_{w}\right.$ and $\left.\alpha_{t}\right)$ are modeled considering this effect and are shown in Eqs. 17 and 18 for the wheeled and tracked vehicles, respectively. Additionally, total resistance forces $\left(F_{T}\right)$ are expressed in Eqs. 19 and 20 for the wheeled and tracked vehicles, respectively.

$$
\begin{aligned}
& \alpha_{w}=\sin ^{-1}\left[\left(G \cdot \mu_{w} \cdot \cos \alpha_{w}\right)-\left(F_{T}^{w}\right)\right] \\
& \alpha_{t}=\sin ^{-1}\left[\left(G \cdot \mu_{t} \cdot \cos \alpha_{t}\right)-\left(F_{T}^{t}\right)\right] \\
& F_{T}^{w}=F_{R} \cdot \cos \alpha_{w}+F_{L}+F_{a} \\
& F_{T}^{w}=R_{\text {in }}+R_{c}+F_{L}+F_{a}
\end{aligned}
$$

where $G$ is the vehicle weight, $\mu_{w}$ is the road adhesion coefficient for the wheeled vehicle, and $\mu_{t}$ is the road adhesion coefficient for the tracked vehicle.

\section{Results and discussion}

In this study, a Matlab/Simulink model was created to investigate the power outputs of the powertrain components, SOC of the battery and vehicle performance of the heavy wheeled and tracked vehicles. In this model, the power requirements of the electric motor and the battery, vehicle range and the maximum climbing potential angle are calculated for two different drive types of heavy vehicle as wheeled and tracked with two drive cycle profiles.

According to the vehicle model for the wheeled and tracked vehicle, electric motor torque outputs are calculated for drive cycles and the results are shown in Figure 3.

The calculation of the motor torque output is shown in Figure 3a. for the HHDDT-Transient Mode. The motor torque of the tracked vehicle is higher than wheeled vehicle type when accelerations in the speed profile are at the highest levels. The motor torque output is also calculated for both vehicle types for the HHDDTCruise Mode in Figure 3b. As a result of these speed profile calculations, the difference between the outputs seems more obvious. Similar to the previous outputs for the HHDDTCruise Mode speed cycle, the motor torque of the tracked vehicle is higher than the motor torque of the wheeled vehicle.

The power values required by the batteries, which give important results about the vehicle energy need, the SOC values of the battery, and the vehicle ranges for the determined speed profile were found using the equations shown in Section 2 . The power requirement of the battery and results are shown in Figure $4 \mathrm{a}-4 \mathrm{c}$. The graphical characteristic of the battery power requirement outputs calculated from the simulation model and shown in Figure 4a-4c are similar to the graphical characteristic of the speed input of the specified road profiles. As a result of the increase in speed in the road profile, the power requirement of vehicle batteries also increases. As can be seen, the battery power requirement of the tracked vehicle is more than that of the heavy wheeled vehicle. 


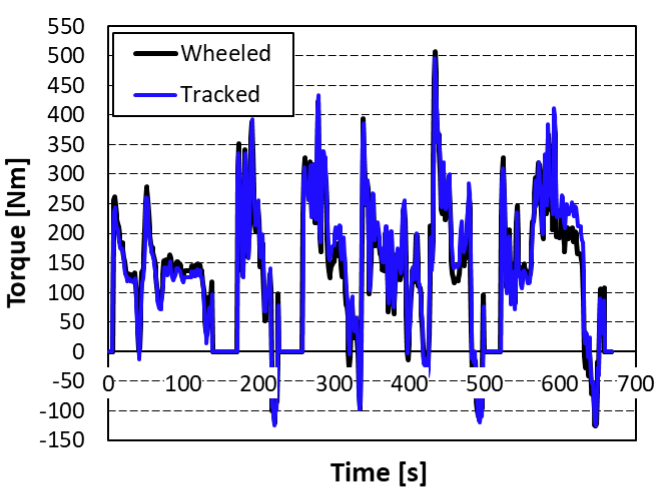

a)

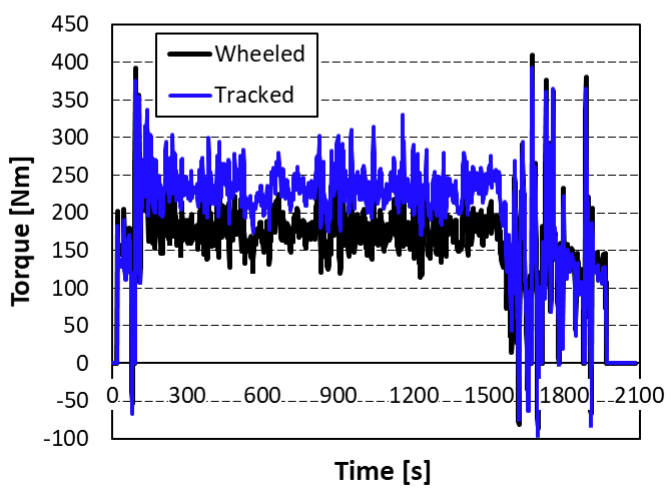

b)

Figure 3. Torque output of EM for HHDDTTransient Mode (a) and HHDDT-Cruise Mode (b)

Figure 4a. shows the power requirement in the battery as a result of defining the values of the HHDDT Transient Mode speed profile as input to the model. Figure $4 \mathrm{~b}$. shows the SOC amount depending on time for a driving cycle. In addition, Figure 4c. shows the energy requirement in the battery as a result of defining the values of the HHDDT Cruise Mode speed profile as input to the model. Figure $4 \mathrm{~d}$. shows the SOC amount depending on time for a driving cycle.

The maximum power requirement is realized at the point where the speed at the $593^{\text {th }}$ second is the maximum, and these values are obtained as $87.5 \mathrm{~kW}$ for the wheeled heavy vehicle and 94.8 $\mathrm{kW}$ for the tracked heavy vehicle for the HHDDT Transient Mode speed profile. As a result of the speed profile and battery capacity parameters, the energy requirement for the tracked heavy vehicle was calculated as $3.18 \mathrm{kWh}$ as a result of the cycle time, while it was calculated as 2.86 $\mathrm{kWh}$ for the wheeled heavy vehicles. However, the maximum power requirement is realized at the point where the speed at the $1157^{\text {th }}$ second is the maximum, and these values were obtained as $98.6 \mathrm{~kW}$ for the wheeled heavy vehicle and $119.12 \mathrm{~kW}$ for the tracked heavy vehicle for the HHDDT Cruise Mode speed profile. As a result of the selected speed profile and battery capacity parameters, the energy requirement for the tracked heavy vehicle was calculated as 33.94 $\mathrm{kWh}$ as a result of the cycle time, while it was calculated as $26.23 \mathrm{kWh}$ for the wheeled heavy vehicles.

On the other hand, the SOC values of the batteries are shown in Figure $4 \mathrm{~b}-4 \mathrm{~d}$. As a result of the higher power requirement of the tracked vehicle during the cycle period, it is observed that the state of charge of the battery decreases faster. As a result of one cycle, the SOC of the battery, which was initially $80 \%$, drops to $79.05 \%$ for the wheeled vehicle, and this value drops to $78.9 \%$ for the tracked vehicle for the Transient Mode driving cycle. However, for the Cruise Mode, the SOC of the battery, which was initially $80 \%$, drops to $71.6 \%$ for the wheeled vehicle, and this value drops to $69.1 \%$ for the tracked vehicle. 


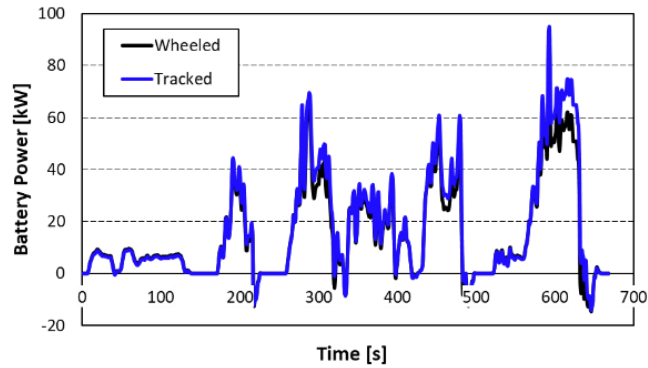

a)

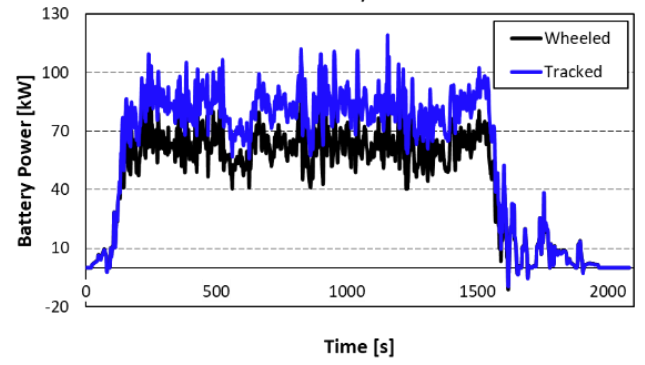

c)

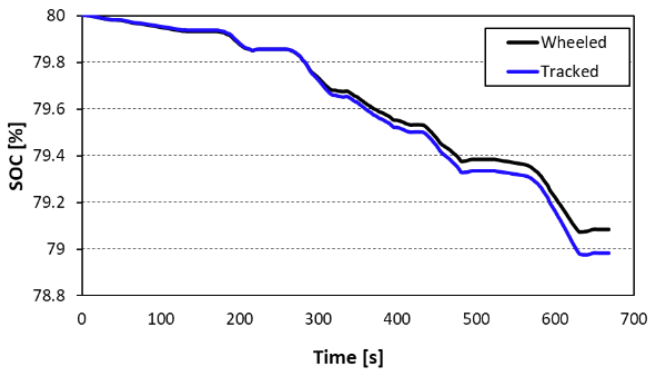

b)

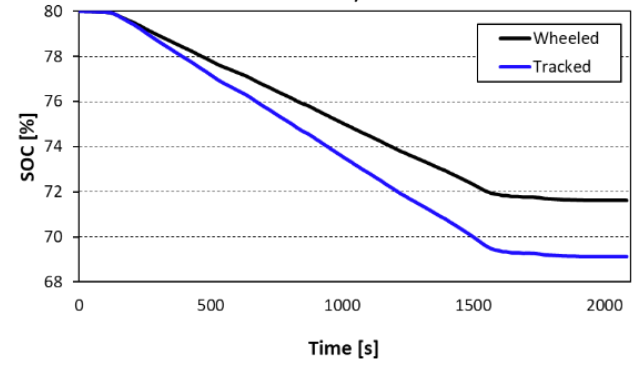

d)

Figure 4. Battery power requirements (a) and SOC history (b) of wheeled and tracked alternatives of the vehicle for The HHDDT Transient Mode speed profile. Battery power requirements (c) and SOC history (d) of wheeled and tracked alternatives of the vehicle for The HHDDT Cruise Mode speed profile

As a result of the simulation where the range values of the vehicles are calculated for the selected battery capacity, the range value is calculated as $241.4 \mathrm{~km}$ for the wheeled vehicle and $218.2 \mathrm{~km}$ for the tracked vehicle for Transient Mode. However, for the Cruise Mode, the range value is calculated as $219.9 \mathrm{~km}$ for the wheeled vehicle and $170 \mathrm{~km}$ for the tracked vehicle. The simulation results were obtained for different vehicle weights and battery capacity with $250 \mathrm{kWh}$. The vehicle ranges are shown in Figure 5.

When the Transient Mode speed profile values, which include lower speeds than the cruise mode speed cycle, were defined as input, the range values were better. The results shown in Figure 5. shows that the highest range values were obtained for the Transient Mode in the wheeled vehicle. In both speed profiles, it was observed that the wheeled vehicle range curves were on the tracked vehicle.

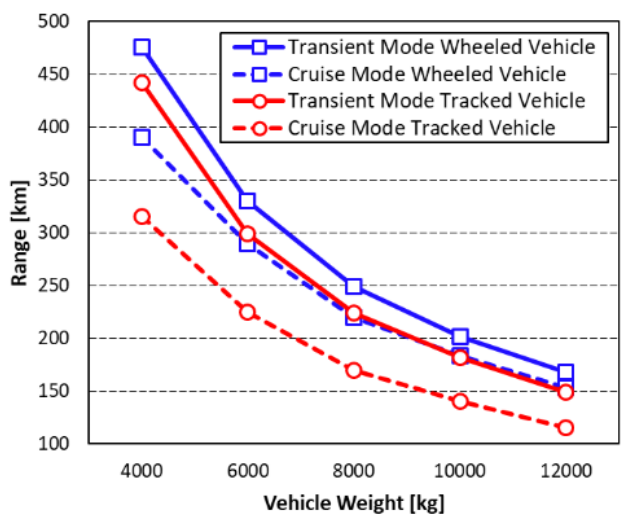

Figure 5. Ranges of wheeled and tracked vehicles with $250 \mathrm{kWh}$ battery for various vehicle weights

The climbing angle potential, which is an important parameter indicating the performance characteristics of vehicles, was calculated by the simulation model for both vehicles, and the results are shown in Table 3 in the degree unit. 
DEÜ FMD 23(69), 913-921, 2021

Table 3. Average climbing angle potential of wheeled and tracked vehicles for various vehicle weights

\begin{tabular}{lllllll}
\hline \multicolumn{2}{l}{ Vehicle Weight $[\mathrm{kg}]$} & $4000 \mathrm{~kg}$ & $6000 \mathrm{~kg}$ & $8000 \mathrm{~kg}$ & $10000 \mathrm{~kg}$ & $12000 \mathrm{~kg}$ \\
\hline $\begin{array}{l}\text { Transient } \\
\text { Mode }\end{array}$ & Wheeled & 33.34 & 33.37 & 33.37 & 33.38 & 33.38 \\
\cline { 2 - 7 } & Tracked & 40.30 & 40.30 & 40.29 & 40.30 & 40.28 \\
\hline $\begin{array}{l}\text { Cruise } \\
\text { Mode }\end{array}$ & Wheeled & 33.20 & 33.36 & 33.38 & 33.43 & 33.43 \\
\cline { 2 - 7 } & Tracked & 39.86 & 39.97 & 39.98 & 40.03 & 40.01 \\
\hline
\end{tabular}

Climbing potential angles were obtained for vehicle weights between $4000 \mathrm{~kg}$ and $1200 \mathrm{~kg}$. The changes in vehicle dimensions together with the vehicle weights were included in the calculations. The maximum climbing angle potential of inclination in this vehicle weight range was calculated as 33.38 degrees in the Transient mode and 33.43 degrees in the Cruise mode for the wheeled vehicle. However, the values were calculated as 40.30 degrees in the Transient mode and 40.03 degrees in the Cruise mode for the tracked vehicle. Although tracked vehicles require more power and their range is lower than a wheeled vehicle, their climbing potential is better.

\section{Conclusion}

Powertrain simulation of a heavy duty vehicle was achieved by Matlab/Simulink for both wheeled and tracked types of the drive. This simulation was repeated for two different speed profiles and the results were compared. As a result, battery power requirements and SOC of the battery were calculated during the drive cycle to determine vehicle range as one of the main vehicle performance criteria for electric vehicles. In addition, the climbing potential of the vehicle alternatives is calculated under dry concrete road conditions. Main conclusions for the Transient Mode can be explained as follows:

- As a consequence of the calculation of battery power and SOC of wheeled and tracked vehicle alternatives, $241.4 \mathrm{~km}$ vehicle range is calculated for the wheeled type; whereas, the range of the tracked vehicle is found as $218.2 \mathrm{~km}$.

- During the cycle time, wheeled vehicle alternative can reach nearly 34 degrees of climbing angle. However, approximately 41 degrees of climbing angle can be achieved by the tracked version of the drive.

The calculations made in the previous simulation were repeated for the Cruise Mode speed profile.
Main conclusions for the Cruise Mode can be explained as follows:

- As a consequence of the calculation of battery power and SOC of wheeled and tracked vehicle alternatives, nearly $220 \mathrm{~km}$ vehicle range is calculated for the wheeled type; whereas, the range of the tracked vehicle is found as $170 \mathrm{~km}$.

- During the cycle time, wheeled vehicle alternative can reach nearly 34 degrees climbing angle. However, approximately 40 degrees of the climbing angle can be achieved by the tracked version of the drive.

It can be clearly stated that the wheeled type is advantageous for vehicle range but the wheeled type has a disadvantage in terms of climbing angle potential compared to the tracked type of drive. More advanced and comprehensive results can be achieved by developing a simulation method including additional drive cycles, battery capacities, road conditions, and steering effect in future studies.

\section{References}

[1] Khalil, G. 2009. Challenges of hybrid electric vehicles for military applications. IEEE Vehicle Power and Propulsion Conference, 7-10 September, Dearborn, MI, USA , 1-3.

[2] Feng, Y., Dong, Z., Yang, J., \& Cheng, R. 2016. Performance modeling and cost-benefit analysis of hybrid electric mining trucks. 12th IEEE/ASME International Conference on Mechatronic and Embedded Systems and Applications (MESA), 29-31 August, Auckland, New Zealand, 1-6.

[3] Verbruggen, F. J., Rangarajan, V., \& Hofman, T. 2019. Powertrain design optimization for a battery electric heavy-duty truck. American Control Conference (ACC), 10-12 July, Philadelphia, PA, USA, 1488-1493.

[4] Hohl, G. H. 2007. Military terrain vehicles, Journal of Terramechanics, Volume 44, Issue 1, p. 23-34. DOI: 10.1016/j.jterra.2006.01.003

[5] Kast, J., Vijayagopal, R., Gangloff Jr, J. J., \& Marcinkoski, J. 2017. Clean commercial transportation: Medium and heavy duty fuel cell 


\section{DEÜ FMD 23(69), 913-922, 2021}

electric trucks, International Journal of Hydrogen Energy, Volume. 42, Issue. 7, p. 4508-4517.

DOI: 10.1016/j.ijhydene.2016.12.129.

[6] Awadallah, M., Tawadros, P., Walker, P., \& Zhang, N. 2017. Dynamic modelling and simulation of a manual transmission based mild hybrid vehicle, Mechanism and Machine Theory, Volume. 112, p. 218-239. DOI:10.1016/j.mechmachtheory.2017.02.011

[7] Mashadi, B., and Crolla, D. 2012. 1st edition. Vehicle powertrain systems. Wiley, $115 \mathrm{p}$.

[8] Mężyk, A., Czapla, T., \& Klein, W. 2009. Hybrid drive application for high-speed tracked vehicle, Journal of KONES, Volume. 16, p. 341-349.

[9] Mallon, K. R., Assadian, F., \& Fu, B. 2017. Analysis of on-board photovoltaics for a battery electric bus and their impact on battery lifespan, Energies, Volume. 10, Issue. 7, p.943.

DOI: $10.3390 /$ en 10070943

[10] Bekker, M. G. 1956. Theory of Land Locomotion. University of Michigan Press. Ann Arbor, 530p.

[11] Wong, J. Y., \& Chiang, C. F. 2001. A general theory for skid steering of tracked vehicles on firm ground. Proceedings of the Institution of Mechanical Engineers, Part D: Journal of Automobile Engineering, Volume. 215, Issue. 3, p.343-355. DOI: $10.1243 / 0954407011525683$

[12] Wong, J. Y. 2008. Theory of ground vehicles. 4th completely revised and enlarged edition. John Wiley \& Sons, $560 \mathrm{p}$

[13] Kitano, M., and M. Kuma, 1977. An analysis of horizontal plane motion of tracked vehicles. Journal of terramechanics. Volume. 14, Issue. 4, p.211-225. DOI: 10.1016/0022-4898(77)90035-0

[14] Muralidhar, N., Himabindu, M., \& Ravikrishna, R. V. 2018. Modeling of a hybrid electric heavy duty vehicle to assess energy recovery using a thermoelectric generator. Energy, 148, 1046-1059. DOI: 10.1016/j.energy.2018.02.023

[15] Kim, D. M., Benoliel, P., Kim, D. K., Lee, T. H., Park, J. W., \& Hong, J. P. 2019. Framework development of series hybrid powertrain design for heavy-duty vehicle considering driving conditions. IEEE Transactions on Vehicular Technology, Volume. 68(7), p. 6468-6480.

DOI: 10.1109/TVT.2019.2914868

[16] Roth, D., Habermehl, C., Jacobs, G., Neumann, S., Juretzki, B., \& Bayer, D. 2021. Optimization-based Component Sizing Method for Electrified HeavyDuty Powertrain Concepts. In IOP Conference Series: Materials Science and Engineering, Volume. 1097 No. 1, p. 012002)

DOI: $10.1088 / 1757-899 X / 1097 / 1 / 012002$

[17] Karaoğlan, M. U., Kuralay, N. S., \& Colpan, C. O. 2019. The effect of gear ratios on the exhaust emissions and fuel consumption of a parallel hybrid vehicle powertrain. Journal of Cleaner Production, 210 1033-1041.

DOI:10.1016/j.jclepro.2018.11.065

[18] Gautam, M., Clark, N., Riddle, W., Nine, R., Wayne, W. S., Maldonado, H., \& Carlock, M. 2002. Development and initial use of a heavy-duty diesel truck test schedule for emissions characterization. SAE Transactions, Volume. 111, p. 812-824.

DOI: $10.4271 / 2002-01-1753$
[19] Karaoğlan, M. U., \& Kuralay, N. S. 2014. PEM YAKIT HÜCRESI MODELI. Engineer \& the Machinery Magazine, Volume. 55, Issue. 657, p.51-58. 